\title{
Culture Trials of Catfish (Clarias Gariepinus) Fingerlings and Juveniles Using Floating Plastic Enclosure System
}

\author{
Sodunke, S A. ${ }^{*} \quad$ George, F. O. A. ${ }^{2} \quad$ Otubusin, S.O. ${ }^{2}$ \\ 1.Ministry of Agriculture, Department of Fisheries, Okelewo, Abeokuta, Ogun State, Nigeria \\ 2.Federal University of Agriculture, Abeokuta, Ogun State, Nigeria. (Department of Aquaculture and Fisheries \\ Management)
}

\begin{abstract}
There is paucity of information on the suitable floating catfish fingerling/nursery production system for juvenile catfish which are in very high demand. The effects of enclosure shape, stocking density, water quality on production of catfish fingerlings and juveniles were evaluated by carrying out two experiments. Experiments involved the use of two plastic enclosure shapes (circular and rectangular of 60litres each) and dosage of eggs $(5 \mathrm{~g}, 10 \mathrm{~g}$, and $15 \mathrm{~g}$ of eggs). There were 3 replicates per treatment (enclosure shape and dosage). Eggs were incubated and hatched in the enclosures. Data collected were number of fingerlings, weight and length, $\mathrm{pH}$ and water temperature inside and outside the enclosures were also monitored. Parameters monitored included number of juveniles, percentage of shooters and suspected cannibalized fish. Data were subjected to ANOVA. Results showed that mean water $\mathrm{pH}$ inside the enclosures were not significantly different $(\mathrm{p}>0.05)$ with respect to enclosure shape. Weight and length of fish at fingerling stage were affected significantly $(\mathrm{p}<0.001)$ by dosage. $5 \mathrm{~g}$ dosage recorded highest mean weight $(3.6 \mathrm{~g})$ and the length $(6.7 \mathrm{~cm})$ of fish at fingerling stage while the $15 \mathrm{~g}$ dosage had the least mean weight $(2.0 \mathrm{~g})$ and length $(5.0 \mathrm{~cm})$. There were no significant differences $(\mathrm{p}>0.05)$ in water temperature and $\mathrm{pH}$ within and outside the enclosure under different egg dosages, percentage of shooters and suspected cannibalized fish were not significantly different $(p>0.05)$ between enclosure shapes. However, the mean weight of fish in circular enclosure was significantly higher $(\mathrm{p}<0.001)$ than in rectangular enclosure. Fish in circular enclosures weighed $7.7 \mathrm{~g}$ each while those in rectangular enclosures weighed 7.0g. Percentage survival and number of shooters were not significantly different $(p>0.05)$ among the three stocking densities. In contrast, number of fish harvested and suspected cannibalized fish were affected significantly $(\mathrm{p}<0.001)$ by stocking densities. Length of fish harvested was significantly different $(p<0.001)$ among the stocking densities. The higher the stocking density the shorter the length of fish harvested. The same inverse trend was observed in weight of shooters, stocking density at 60 fish/enclosure yielded the lightest shooters (6.4g) compared with the highest $(8.3 \mathrm{~g})$ in $15 \mathrm{fish} /$ enclosure. There was no significant difference $(\mathrm{p}>0.05)$ in number of shooters under the different stocking densities, however it is concluded that lower stocking density is preferred to higher stocking density. It is therefore recommended that enclosure of either shape could be adopted.
\end{abstract}

DOI: $10.7176 / \mathrm{JBAH} / 11-14-04$

Publication date:July $31^{\text {st }} 2021$

\section{INTRODUCTION}

Aquaculture is the farming of aquatic organisms such as fish, crustaceans, molluscs and aquatic plants in controlled conditions (Jhingran, 1987). Aquaculture was further described as production of a crop in the aquatic medium. The crop may be that of an animal or a plant, examples are Finfish: Tilapia, carp, trout, milkfish, bait minnow, yellow tail, Mullet, Catfish. Shell fish: shrimps, prawns, mussels, oysters (e.g Japanese pearl oyster Pincatafucata). Plants: include water chestnut (Trapanatanus), red alga of Japan, "Norie" (Porphyra), red alga of Philippines and U.S.A (Eucheuma), brown alga of Japan "Wakame" (Ondaria) (Jhingran, 1987). Aquaculture, probably the fastest growing food producing sector, now accounts for almost 50 percent of the world's food fish and is perceived as having the greatest potential to meet the growing demand for aquatic food. Given the projected population growth over the next two decades, it is estimated that at least an additional 40 million tons of aquatic food will be required by 2030 to maintain the current per capital consumption (FAO, 2006). From an activity that was primarily Asian, Aquaculture has now spread to all the continents. From an activity that was focused on freshwater fish, particularly the cyprinids, it now encompasses all aquatic environments and many aquatic species. Clearly, its Asian origin and its carp-focused beginnings are still evident in the present distribution and the dominance of cyprinids. The present situation in terms of natural resources, the environment and population along with advances in biotechnology, marine engineering and in the movement of goods and services, bring with it greater potential as well as more complex challenges in the development of aquaculture (FAO 2006). World aquaculture has grown tremendously during the last fifty years from a production of less than a million tonnes in the early 1950 to 59.4 million tonnes by 2004. This level of production had a value of $\$ 70.3$ billion of which 41.3 million tonnes, or 69.6 percent, was produced in China and 21.9 percent from the rest of Asia and the Pacific region. The Western European region contributed 3.5 percent with 2.1 million tonnes (valued at $\$ 5.4$ billion), while the central and Eastern Europe region contributed 250,000 tonnes, or 0.4 percent. 
Latin America and the Caribbean and North America contributed $2.3 \%$ and $1.3 \%$ respectively. Finally, production from the Near East and North Africa region and Sub-Sahara Africa accounted for 0.9 percent and 0.2 percent respectively of the global total for 2004 (FAO, 2004).

Three categories of modern aquaculture are distinguished based on the intensity of the system. These are:

a) Extensive system in which neither feed nor fertilizer inputs are made

b) Semi-intensive systems where some supplementary fertilizers and /or feed are provided and

c) Intensive systems which rely mainly on externally sourced inputs (Pullin, 1989).

Fish ponds represent the most widespread form of modern aquaculture in Africa, the practice having been introduced into more than 40 countries of the estimated 270,000-335,000 ponds that have been constructed; perhaps less than $25 \%$ remain in operation. Most development has been some semi-commercial activity, based mainly on more intensive operations. In contrast, there has been relatively little development either of extensive rice-fish culture or of intensive pond, pen, cage, tank, and raceway systems (FAO, 1998). Concrete or metal tanks have been used for farming trout in Zimbabwe and for turtle rearing in Reunion. In Kenya, tanks and raceways have been used since 1975 for the intensive culture of Tilapia. Similar example can be found in Egypt, Zambia and Zimbabwe. The technique is now being considered for application in the Congo and Nigeria (Balarin and Haller, 1982).

Deep parts of lagoons, lakes, reservoirs or water courses can support cage culture, and shallow areas can be utilized for Fish-raising in pens. Cage culture has been tested in Egypt, Kenya, Nigeria, Tanzania and Zimbabwe and Tilapia are now raised commercially in cage in Cote d'ivoire (Balarin and Haller, 1982). There has been only limited development of pen aquaculture in Africa. It has been tested in Benin, Burkina Faso, Cote d'ivore, and Togo, but the only major development so far has occurred in Benin as an alternative to the traditional acadja system. Yields appear to be in the range of 25-220 t/ha/year (P. morrissons, pors.com).

Cages are enclosures; either round or with four sides (walls) and a base or bottom. Some even though optional, have top cover to prevent fish jumping out or aerial intruders like birds preying on fish stocked in the cages (Otubusin, 1989)._Fish cage culture is the art of growing fish from seed to marketable size in cages (Aigbadon, 1986). Fish cage culture can be considered as an advanced type of aquaculture. Its productivity is 10 to 20 times higher than that of pond culture for comparable inputs and area (Aigbadon, 1986). The plastic enclosure nursery is sufficiently simple and affordable compared to modern land-based hatcheries. Hence, the technology can be transferred almost directly to small-scale fish farmers with little modifications. Multiplication of this plastic hatchery/nursery idea could potentially increase employment opportunities for poor residents in the riverine areas of Nigeria.

\section{Objectives}

- To evaluate the efficiency of plastic enclosure system for fish seed production from Eggs $\rightarrow$ Hatchlings $\rightarrow$ Alevins $\rightarrow$ Fry $\rightarrow$ Fingerlings $\rightarrow$ Juveniles

- To evaluate the performance of circular and rectangular plastic enclosures in C. gariepinus seed rearing.

- To evaluate the effect of fish stocking density on the performance of $C$. gariepinus in plastic enclosure system.

\section{MATERIALS AND METHODS}

\section{The experiment site}

The site for the experiment was the 4-hectares Odeda farm institute reservoir, situated along Abeokuta-Ibadanroad, Eweje, Odeda Local Government Area.

\section{Plastic enclosures}

Circular plastic enclosures of volume 60 litres (black colour) (Plate A) and rectangular plastic enclosure (white colour) of volume 60 litres were used (Plate B. These were purchased from a local market at Mokola in Abeokuta.

\section{Netting materials}

Nylon type of mosquitoes' net of $12 \mathrm{~mm}$ mesh size (white colour) was used to line the plastic enclosures internally on all sides, including the vertical $2.54 \mathrm{~cm}$ pipe inside the enclosures. Nylon twine were used to sew the netting materials with the aid of shoe makers/cobbler needle

\section{Frame work, floats and mooring devices}

PVC pressure pipes of diameter $2.54 \mathrm{~cm}$ and series of PVC fittings of the same size (i.e elbow, tee, socket, diameter $2.54 \mathrm{~cm}$ or 1 inch) were used with the aid of PVC gum to construct the frame work (Plate C). PVC pipes, yellow plastic kegs (25litres) were used for the PVC raft as floats. Wooden pegs/bamboo and twine kuralon (no.15) ropes were used to tie the cage around the bamboo. 


\section{Experimental fish}

Gravid C. gariepinus brood stock were purchased from Fish House Konsult, Olokuta village off Kemta Idi-aba Housing Estate, Abeokuta. The size of the fish (brood stock) ranged from $800 \mathrm{~g}-1.5 \mathrm{~kg}$ and were all matured enough for the exercise.

\section{Plastic enclosures design/layout}

The design of the enclosure and framework were done such that all the materials used were made of plastic materials. $2.54 \mathrm{~cm}$ (i.e one inch) pressure pipe and its fittings were used for the construction of the frame to form a rectangular raft (design) of size $4 \mathrm{~m} \times 2.8 \mathrm{~m}(\mathrm{LxB})$. The rafts were held together using PVC gum. The raft was also braced with $2.54 \mathrm{~cm}$ pipes cut to small sizes to provide support such that the raft was strong enough to carry the plastic enclosures attached to it (Plate C).

\section{Design of the enclosures}

The plastic enclosures (rectangular and circular were perforated using hot iron rod of $1 / 2 \mathrm{inch}(1.27 \mathrm{~cm})$ diameter. These perforations were done evenly round the body of enclosures with interval of $1 \mathrm{~cm}$ in between two holes. A gap of $5 \mathrm{~cm}$ from the bottom of each enclosure to the point in which the perforation begins was left. This was done to enable the hatchlings to settle at bottom and absorbed their yokes before swimming around and to prevent small ones from escaping immediately after hatching. The bottom of the enclosures was only perforated at one point which happened to be the centre. This was done with the aid of $2.54 \mathrm{~cm}$ (one inch) iron rod (Plates $\mathrm{D}$ and E). The perforation at the bottom was blocked with a plastic fitting- $2.54 \mathrm{~cm}$ tank back not with $2.54 \mathrm{~cm}$ PVC pipe cut to a size of $20 \mathrm{~cm}$ and fixed to stand vertically inside each enclosures after the pipe itself had been perforated using soldering iron. This perforation gave room for proper water circulation and aeration (Plate E).

\section{Screening of the enclosures}

All the enclosures which were eighteen in number nine (9) circular and nine (9) rectangular were all screened inside with white mosquito net using twine of size $210^{\mathrm{D}} / 9$ to fasten it around the edges of enclosures to prevent the hatchlings from escape. The floats were made from well-sealed 25 litres plastic kegs. These kegs were fastened around the raft using kuralon twine of size (15). The same size of twines was also used to fasten the eighteen enclosures into the raft. These improvised kegs used as floats were arranged strategically at the edge and middle of the raft for balanced floatation and also done to provide a freeboard for the entire enclosures.

\section{The system unit}

The cage system (i.e raft and enclosures) (Plate F). After completion, the cage unit was launched by manual carrying into the reservoir and paddled to the desired location on the reservoir. The location was about $5 \mathrm{~m}$ depth and adjacent to the reservoir central monk (Plate F). The system was then fixed using the bamboo poles or the stakes vertically into the bottom mud at four corners of the frame and where necessary. The entire system was covered with mosquito net to prevent predatory birds, dragon flies or any foreign bodies from entering the cage through action of winds (Plate F). 


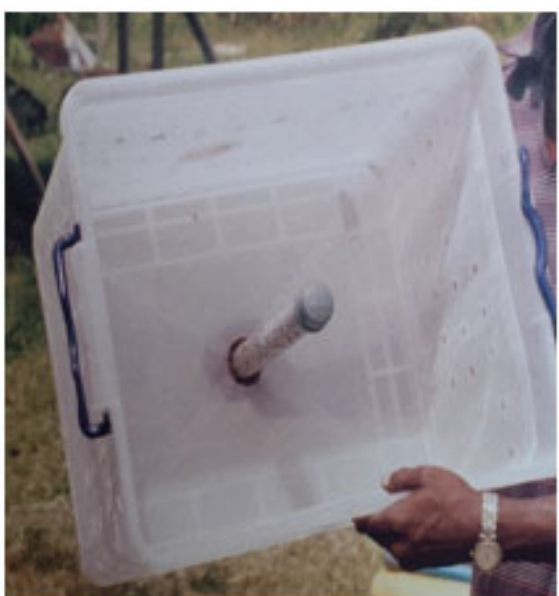

B

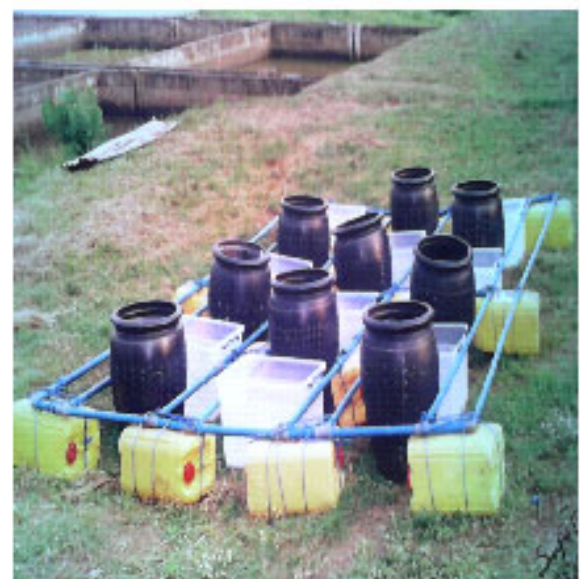

D

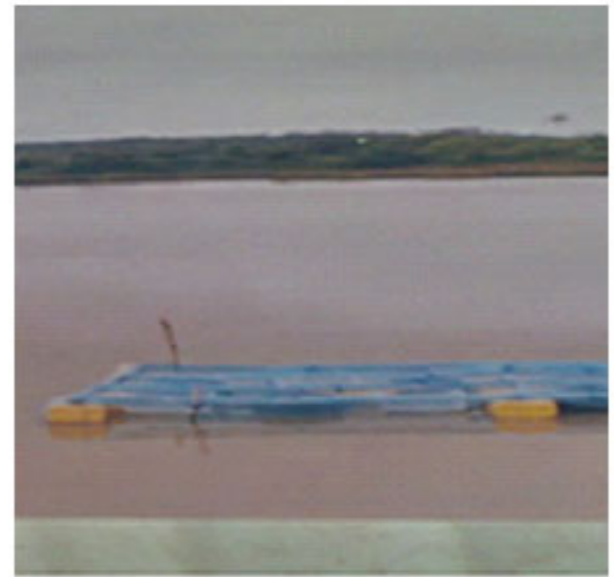

$\mathrm{F}$

Plates A-F: Showing the arrangements and construction of the cage unit. 
Culture trials

Four gravid females and two matured males were selected and used for experiment 1 . The brood stocks were weighed and then injected with ovaprim at dosage of $0.5 \mathrm{ml} / \mathrm{kg}$. The female brood stocks were put separately in a bowl covered with wire gauze after injection for 10hours (latency period). The weight of the female brood stocks was taken before and after stripping. The weight of the eggs stripped from each female was taken. The number of eggs in 1gram of egg was counted and the eggs collected in each of the female brood stock were mixed together. The milt of the males brood stock were collected and mixed with $5 \mathrm{ml}$ of saline $(0.9 \%$ saline solution) solution per testes to fertilize the mixed female eggs after which the eggs were incubated at $5 \mathrm{~g}, 10 \mathrm{~g}$ and $15 \mathrm{~g}$ (corresponding to treatments I, II and III and replicated thrice in a complete randomized design) on kakaban spread inside the floating plastic enclosure for 24hours. However, extra 3hours was given for total hatching to take place. The hatchlings were left in the enclosures after removing the kakaban. Feeding of the fry with artemia started after the third day and the fish were fed with different sizes of feed granules (Coppens) for 42days. In experiment 2, the total number of fingerlings and their weight in each enclosure were taken to determine yield/treatment. The fish were then re-distributed randomly in the enclosures at stocking densities of 15,30 , and 60 per enclosure (treatment I, II and III respectively) and replicated thrice in a complete randomized design (CRD), the initial weight taken and fed at $5 \%$ body weight for 4 times a day. The fish were reared to juveniles in each enclosure for 28 days. Fish performance in enclosure of different shapes were evaluated after the final weight was taken. The fish feeds were procured from reputable feed producing company in Abeokuta, Ogun State. The fish were fed with artemia $0.2 \mathrm{~mm}$ for the first 11 days, Coppens of sizes $0.3 \mathrm{~mm}-0.8 \mathrm{~mm}$ were given till they got to fingerlings stage ( 42 days). While feed sizes $0.8 \mathrm{~mm}-2 \mathrm{~mm}$ were used to rear the fish fingerlings to juveniles, at $5 \%$ of their body weight for the last 4 weeks.

\section{Fish sampling and sorting}

Fish sampling and sorting were carried out in the morning between 7:30 and 9:00am using scoop net. The weight of the fish was taken using Electronic balance scale. The fish were harvested after the 70days culture period, by moving the cage system to the shore. All the fish inside the enclosures were scooped out for mass weighing per enclosure and the total number of fish in each enclosure counted, noting the number of shooters and their weight per enclosure.

\section{Fish performance parameters}

Data on fish performance were recorded twice a week. The weight of individual fish was determined with an electronic scale of model KERN 572, the Standard Length was determined with a measuring board. The experimental tanks were inspected daily to remove and record dead fish. Fish stocking density, weight gain, survival rate, mean length gain, number of shooters and suspected cannibalized fish were determined as follows. All these parameters were computed as described by Amisah et al., (2009):

(i) Weight gain $=$ Final weight of fish - Initial weight of fish

(ii) Suspected cannibalized fish was calculated as:

$$
\mathrm{M}=\frac{\left(\mathrm{N}_{\mathrm{o}}-\mathrm{N}_{\mathrm{t}}\right) \times 100 \%}{\mathrm{~N}_{\mathrm{o}}}
$$

Where:

$\mathrm{N}_{\mathrm{o}}=$ Number at the start of the experiment

$\mathrm{N}_{\mathrm{t}}=$ Number at the end of the experiment

\section{Water quality parameters}

The physical and chemical parameters of the water determined were $\mathrm{pH}$, Temperature, Dissolved oxygen and ammonia. Water temperature, $\mathrm{pH}$ and dissolved oxygen (DO) were measured daily with mercury in-glass thermometer, pH meter (WTW Ph 330) and DO meter (MW600), respectively while ammonia concentration was estimated in the laboratory using APHA standard procedure.

\section{The statistical analysis}

The experiment adopted the completely randomized design. Analysis of variance (ANOVA) and student $t-$ test were statistical tools used to determine the stocking density on fish performance, survival rate of $C$. gariepinus and water parameters of the two different culture environments.

\section{RESULTS}

Effect of shapes of enclosures on fish hatchability

The effects of the shapes of enclosures on fish hatchability are shown in Table 1. Mean number of fish after hatching, weight and length of fingerlings was higher in circular enclosures and statistical differences $(p<0.05)$ 
exist between the enclosures.

\section{Dosage effect on fish production}

Mean dosage rate was higher for number, weight and length of fingerlings, in the circular enclosure than the rectangular enclosure. It was observed that the number of fingerlings was highest in $15 \mathrm{~g}$ for both enclosures and the lowest was recorded in $5 \mathrm{~g}$ dosage respectively. Weight of fingerlings followed the same pattern with the highest dosage recorded in $5 \mathrm{~g}$ in both enclosure and the lowest indicate $15 \mathrm{~g}$ respectively while the mean dosage was higher in circular tank. Length of fingerlings had the highest mean dosage in circular with $5 \mathrm{~g}$ dosage been superior in the circular and $15 \mathrm{~g}$ dosage indicate the lowest in the rectangular enclosure Table 2.

\section{Stocking density on fish performance}

The stocking density and survival rate of fish in enclosure are shown in Table 3. Treatment I had the highest weight gained after harvest, followed by 30 and 60 in both culture media. The highest mean survival rate (95.6 \pm 2.16 and $88.9 \pm 2.01)$, number of shooters $(1.3 \pm 0.11$ and $1.7 \pm 0.21)$ and suspected cannibalized fish ( $7.00 \pm 0.37$ and $7.00 \pm 0.19)$ while the lowest $(2.3 \pm 0.11$ and $2.5 \pm 0.12,87.81 \pm 1.96$ and $83.3 \pm 2.07,0.3 \pm 0.16$ and $1.3 \pm 0.12$ and $1.00 \pm 0.00$ and $2.10 \pm 0.28$ ) were observed in 60 each respectively in the circular and rectangular enclosure. Mean standard length at harvest was highest for 15 and lowest in 60 respectively for both culture traits. There was significant differences $(p<0.05)$ in number of fish harvested, weight of fish harvested and mean length of the fish harvested.

Table1: Shows the effects of shapes on fish hatchability

\begin{tabular}{ccc}
\hline & \multicolumn{2}{c}{ Shape } \\
& $\begin{array}{c}\text { Circular enclosure } \\
\text { Mean } \pm \text { SE }\end{array}$ & $\begin{array}{c}\text { Rectangular enclosure } \\
\text { Mean } \pm \text { SE }\end{array}$ \\
\hline Number of fish after hatching & $43 \pm 2.83^{\mathrm{a}}$ & $37 \pm 1.89^{\mathrm{b}}$ \\
Weight of fingerlings $(\mathrm{g})$ & $2.9 \pm 0.10^{\mathrm{a}}$ & $2.7 \pm 0.08^{\mathrm{b}}$ \\
length of fingerlings $(\mathrm{cm})$ & $5.9 \pm 1.34^{\mathrm{a}}$ & $5.7 \pm 1.12^{\mathrm{b}}$ \\
\hline
\end{tabular}

${ }^{\mathrm{a}, \mathrm{b}}$ Means within the same row with different superscripts differ significantly $(\mathrm{P}<0.05)$

Table 2: Illustrates the dosage effect on fish performance

\begin{tabular}{lcccccccc}
\hline Dosage/Performance & \multicolumn{3}{c}{ Circular } & \multicolumn{5}{c}{ Rectangular } \\
& $\mathrm{TR}_{1}$ & $\mathrm{TR}_{2}$ & $\mathrm{TR}_{3}$ & & $\mathrm{TR}_{1}$ & $\mathrm{TR}_{2}$ & $\mathrm{TR}_{3}$ \\
& $5 \mathrm{~g}$ & $10 \mathrm{~g}$ & $15 \mathrm{~g}$ & $\mathrm{Mean} \pm \mathrm{SD}$ & $5 \mathrm{~g}$ & $10 \mathrm{~g}$ & $15 \mathrm{~g}$ & $\mathrm{Mean} \pm \mathrm{SD}$ \\
\hline Number of fingerlings & 17 & 43 & 69 & $43 \pm 21.23$ & 14 & 33 & 63 & $36.67 \pm 24.70$ \\
Weight of fingerling $(\mathrm{g})$ & 3.7 & 2.9 & 2.1 & $2.9 \pm 25.55$ & 3.4 & 2.6 & 1.9 & $2.63 \pm 0.75$ \\
Length of fingerling $(\mathrm{cm})$ & 6.9 & 5.9 & 5 & $5.9 \pm 1.75$ & 5.9 & 6.6 & 4.9 & $5.8 \pm 0.85$ \\
\hline
\end{tabular}

$\mathrm{SD}=$ Standard deviation, $\mathrm{TR}_{1}=5 \mathrm{~g}, \mathrm{TR}_{2}=10 \mathrm{~g}, \mathrm{TR}_{3}=15 \mathrm{~g}$

Table 3: Effects of stocking density on fish performance

\begin{tabular}{|c|c|c|c|c|c|c|}
\hline \multirow{3}{*}{ Stocking density } & \multicolumn{3}{|c|}{ Circular } & \multicolumn{3}{|c|}{ Rectangular } \\
\hline & $\begin{array}{c}\text { Treatment } \\
1\end{array}$ & $\begin{array}{l}\text { Treatment } \\
2\end{array}$ & $\begin{array}{l}\text { Treatment } \\
3\end{array}$ & $\begin{array}{c}\text { Treatment } \\
1\end{array}$ & $\begin{array}{l}\text { Treatment } \\
\quad 2\end{array}$ & $\begin{array}{c}\text { Treatment } \\
3\end{array}$ \\
\hline & 15 & 30 & 60 & 15 & 30 & 60 \\
\hline Weight of fish stocked (g) & $2.3 \pm 0.11^{\mathrm{a}}$ & $2.6 \pm 0.23^{\mathrm{a}}$ & $2.6 \pm 0.20^{\mathrm{a}}$ & $2.5 \pm 0.12^{\mathrm{a}}$ & $2.7 \pm 0.08^{\mathrm{a}}$ & $2.6 \pm 0.18^{\mathrm{a}}$ \\
\hline & $14.0 \pm 1.22$ & $26.0 \pm 0.97$ & $53.10 \pm 1.3$ & $13.00 \pm 1.1$ & $25.00 \pm 1.8$ & $53.23 \pm 1.4$ \\
\hline Number of fish harvested & 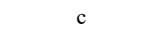 & $\mathrm{b}$ & $6^{\mathrm{a}}$ & $3^{c}$ & $9^{b}$ & $8^{\mathrm{a}}$ \\
\hline & $95.6 \pm 2.16$ & $87.81 \pm 1.9$ & $88.9 \pm 1.56$ & $86.7 \pm 1.35$ & $83.3 \pm 2.07$ & $88.9 \pm 2.01$ \\
\hline Percentage survival (\%) & $\mathrm{a}$ & $6^{\mathrm{a}}$ & $\mathrm{a}$ & $\mathrm{a}$ & a & $\begin{array}{c}\mathrm{a} \\
6.00 \pm 0.33\end{array}$ \\
\hline Weight of fish after harvest $(\mathrm{g})$ & $8.4 \pm 0.56^{\mathrm{a}}$ & $8.1 \pm 0.87^{\mathrm{a}}$ & $6.7 \pm 0.19^{b}$ & $8.3 \pm 0.39^{\mathrm{a}}$ & $6.9 \pm 0.48^{\mathrm{b}}$ & $\mathrm{c}$ \\
\hline $\begin{array}{l}\text { Mean length of fish after } \\
\text { harvest }(\mathrm{cm})\end{array}$ & $\begin{array}{c}12.3 \pm 0.92 \\
\text { a }\end{array}$ & $\begin{array}{l}11.3 \pm 0.76 \\
\text { ab }\end{array}$ & $9.6 \pm 0.18^{c}$ & $\begin{array}{c}12.2 \pm 0.96 \\
\mathrm{ab}\end{array}$ & $\underset{\mathrm{bc}}{10.5 \pm 0.19}$ & $9.3 \pm 0.49^{c}$ \\
\hline Percentage shooters $(\%)$ & $2.2 \pm 0.09^{\mathrm{a}}$ & $3.3 \pm 0.07^{\mathrm{a}}$ & $2.2 \pm 0.10^{\mathrm{a}}$ & $4.4 \pm 0.09^{\mathrm{a}}$ & $5.6 \pm 0.06^{\mathrm{a}}$ & $2.2 \pm 0.11^{\mathrm{a}}$ \\
\hline Percentage mortality ( $\%)$ & $\begin{array}{c}1.00 \pm 0.00 \\
\mathrm{a}\end{array}$ & $\begin{array}{c}4.00 \pm 0.37 \\
\mathrm{a}\end{array}$ & $\begin{array}{c}7.00 \pm 0.33 \\
\mathrm{a}\end{array}$ & $\begin{array}{c}2.10 \pm 0.28 \\
\mathrm{a}\end{array}$ & $\begin{array}{c}5.00 \pm 0.08 \\
\mathrm{a}\end{array}$ & $\underset{\mathrm{a}}{7.00 \pm 0.19}$ \\
\hline
\end{tabular}

Mean values on the same row with different superscripts are significantly different $\mathrm{p}<0.05$ Treatment $1=15$ number of fingerlings, Treatment $2=15$ number of fingerlings, Treatment $3=15$ number of fingerlings 


\section{Water quality Parameters}

The result of water quality parameters measure in the circular enclosure was temperature (28.3 \pm 1.05$), \mathrm{pH}$ (7.7 \pm 0.30$)$, dissolved oxygen $(6.17 \pm 0.16)$ and ammonia $(0.924 \pm 0.10)$. In rectangular tank experiment mean

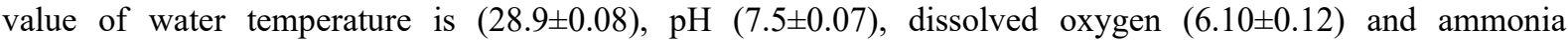
$(1.082 \pm 0.05)$

Table 4: Water quality parameters in the circular and rectangular enclosure

\begin{tabular}{lcccc}
\hline & \multicolumn{2}{c}{ Circular } & \multicolumn{2}{c}{ Rectangular } \\
Parameters & Inside enclosure & Outside enclosure & Inside enclosure & Outside enclosure \\
\hline Temperature $\left({ }^{\circ} \mathrm{C}\right)$ & $28.8 \pm 0.65$ & $28.8 \pm 1.05$ & $28.9 \pm 0.08$ & $28.8 \pm 0.10$ \\
pH & $7.7 \pm 0.30$ & $7.6 \pm 0.07$ & $7.5 \pm 0.05$ & $7.5 \pm 0.07$ \\
Dissolved oxygen $(\mathrm{mg} / \mathrm{l})$ & $5.28 \pm 0.36$ & $6.17 \pm 0.16$ & $5.18 \pm 0.73$ & $6.10 \pm 0.12$ \\
Ammonia $(\mathrm{mg} / \mathrm{l})$ & $0.924 \pm 0.16$ & $0.851 \pm 0.06$ & $1.082 \pm 0.05$ & $1.009 \pm 0.16$ \\
\hline
\end{tabular}

\pm Mean and standard error

\section{DISCUSSION AND CONCLUSION}

Catfish is an important contributor to both inland fisheries and aquaculture in Nigeria (Jamabo and Keremah, 2009). The study on plastic enclosure for incubating C. gariepinus eggs is relatively new. Hence, the results obtained will be of tremendous help in the field. The difference observed on growth performance and water quality is similar to results of Akinwole and Akinnuoye (2012) in culture enclosure of three different shapes. They reported that there were no differences in weight gain and other water quality parameters. The number and weight of fingerlings obtained after hatching are of utmost importance in C. gariepinus production. It determines the profit margin as the sale of the newly hatched fish depends on number and the livability on weight.

On water quality, the optimum temperature recommended for rearing and conditioning brood fish for artificial propagation is $25^{\circ} \mathrm{C}$ (Akinwole and Akinnuoye, 2012). A minor fluctuation in this optimum temperature may be allowed. This is a prerequisite for quantitatively and qualitatively adequate gonadal development year-round. Water temperature, inside and outside the cages in this study was between 28.8 and $28.9^{\circ} \mathrm{C}$. Akinwole and Akinnuoye (2012) reported a temperature range of $24.93-25.93^{\circ} \mathrm{C}$ in circular tank, $25.03-26.13^{\circ} \mathrm{C}$ in rectangular tank and $24.97-26.23^{\circ} \mathrm{C}$ in square tank. The temperature obtained in present study is within the range recommended by Akinyemi (1988) who recorded temperature between $22-35^{\circ} \mathrm{C}$ for catfish culture. Water temperature influences the onset of spawning in fishies, aquatic vegetation growth and the biological demand for oxygen in ponds. As water temperature increases, it holds less oxygen. Additionally, plants and animals use more oxygen due to increased respiration rates.

Water in circular cage had higher $\mathrm{pH}$ than in rectangular cage. This may be due to free flow of water in rectangular cage. The $\mathrm{pH}$ recorded is near neutral or slightly alkaline in both culture media. Most aquatic organisms cannot tolerate extremely high or low $\mathrm{pH}$. Young fish are sensitive to $\mathrm{pH}$ levels below 5 and may die at these low $\mathrm{pH}$ values. High $\mathrm{pH}$ levels (9-14) can harm fish by denaturing cellular membranes. Alteration in water $\mathrm{pH}$ does affect other aspects of water chemistry and thereby indirectly affecting the young fish. FAO (2013) recommended $\mathrm{pH}$ of 6-9 for Clarias gariepinus. Fish have an average blood $\mathrm{pH}$ of 7.4, so pond water with a $\mathrm{pH}$ close to this is optimum. An acceptable range would be 6.5 to 9.0. Fish can become stressed in water with a $\mathrm{pH}$ ranging from 4.0 to 6.5 and 9.0 to 11.0. Death is almost certain at a $\mathrm{pH}$ of less than 4.0 or greater than 11.0. Pond water $\mathrm{pH}$ fluctuates throughout the day due to photosynthesis and respiration by plants and vertebrates respectively. Typically, $\mathrm{pH}$ is highest at dusk and lowest at dawn. This is because nighttime respiration increases carbon dioxide concentrations that interact with water producing carbonic acid and lowering $\mathrm{pH}$. This can limit the ability of fish blood to carry oxygen.

The quantity of eggs fertilized determines the number of fingerlings harvested. However, the higher the density of fry resulting from higher dose of eggs $(15 \mathrm{~g})$ led to reduced weight and length in harvested fingerlings. Jamabo and Keremah (2009) concluded that stocking density had significant effect on growth, survival and food conversion of fingerlings of $C$. gariepinus. Similar report was given by Hengsawat et al. (1997) in African catfish. Jamabo and Keremah (2009) reported that stocking density and the volume of water per fish is a significant factor in determining production in cages. Higher stocking density is stressful for fingerlings. The three dosages of eggs incubated however resulted in similar water $\mathrm{pH}$ and temperature.

Rearing the fingerlings to juvenile stage in cages requires adequate care to ensure good production. In this study, higher mean weight of juvenile recorded in circular enclosure may be due to psychological influence of the circular shape since they tend to move in circle. This gives fishes the impression that they have enough space and thus affects their welfare. The present result is in contrast to the report of Akinwole and Akinnuoye (2012). The incidence of mortality recorded was as a result of cannibalism which was higher at higher density than in lower density. This is due to competition. Weight and length of juveniles were inverse relative to stocking density. This is due to the same reasons adduced above. 


\section{Conclusion}

From the present study, it can be concluded that water in circular plastic enclosure had higher pH than water in rectangular plastic enclosure. It was also observed that the weight and length of fingerlings in circular and rectangular enclosure were similar while the quantity of eggs incubated had positive influence on the number of fingerlings harvested after 6 weeks but negative influence on the weight and length of fingerlings. It can also be concluded that higher stocking density of fingerlings resulted in lower weight and length.

\section{Recommendation}

It is therefore recommended that:

(i) Enclosure of either shape can be adopted

(ii) Lower stocking density is preferred to higher density

(iii) Small scale fish farmers can come together under a cooperative union for a profitable commercial use of this simple and cheap culture system.

\section{REFERENCES}

Aigbadon, B.V.1986. Commercial cage fish culture In: (1986). Fisheries Society of Nigeria Proceeding. 32pp.

Akinwole,A.O. and Akinnuoye, F. C. 2012. Effects of the shape of culture tanks on production of the African Catfish Clarias gariepinus juveniles. Journal of Agriculture and Social Research 12(1):11-18.

Akinyemi, O. 1988. Water Quality and Pond Management In: A.M. Ajani (ed).Proceedings of the Nationwide Fish Farmers Workshop.pp.101-106.

Amisah, S; Oteng, M. A and Ofori, J. K. 2009. Growth performance of the African catfish, Clarias gariepinus, fed varying inclusion levels of Leucaena leucocephala leaf meal. J. Appl. Sci. Environ. Manage. Vol. 13(1) $21-26$

Balarin, J. D. Haller, R. D. 1982. The intensive culture of Tilapia in tanks, raceways and cages. In: Muir, J.F, Roberts, R.J. (Eds), Recent Advances in Aquaculture. Westview, Boulder. 265-356.

FAO 1998.Definition of Aquaculture. IPFC/WPA/WP2, $7^{\text {th }}$ Session on the IPFC.Working party of Expert on Aquaculture,1-6 August 1988.Bangkok.3p

FAO 2004. The State of World Fisheries and Aquaculture.FAO Fisheries Development Rome.153pp.

FAO 2006. State of World aquaculture. FAO Fisheries Development Rome.153pp.

FAO 2013. Food and Agriculture Organisation. Seed production: Mass production fry and fingerlings of the African catfish Clarias gariepinus. FAO Corporate

Hengsawat,K.,Ward, F.J.and Jaruratjamorin,P. 1997.The effect of stocking density on yield, growth and mortality of African catfish (Clarias gariepinus Burchell 1822) cultured in cages. Aquaculture 152(1-4):6776

Jamabo,N.A. and Keremah,R.I. 2009. Effects of stocking density on the growth and survival of the Fingerlings of Clarias gariepinus (Burchell,1822).Journal of Fisheries International 4(4):55-57.

Jhingram,V.G. 1987. Introduction to aquaculture. Invited lecture presented at the African Regional Aquaculture Center, Port Harcourt, Nigeria (ARC/REP/87/WP/u).

Otubusin, S. O. 1989. Fish culture in Cages, Pen and Enclosures: A possibility of meeting the Fish Demand in Nigeria. In: 1989 Fisheries Society of Nigerian Conference Proceedings. A. D. Oniya and G. N. Asal (eds) $9-15 \mathrm{pp}$.

Otubusin,S.O. 1986. Cage, Pen and Enclosure fish culture In: Fisheries Enterprises and Information Brochure KLRI, New-Bussa E.O. Ita (ed) pp.20-25, 83-89.

Pullin, R. S. V 1989. Third-world aquaculture and the environment. Naga, the ICLARM Quartely, Vol 12, No 1. $\operatorname{Pp} 10-13$ 